\title{
The Practice and Indication of Incremental Reform for Financial Industry in China
}

\author{
GUO QING ${ }^{1, a}$ \\ ${ }^{1}$ State Grid Energy Research Institute, North Area of Future Technology City, Changping District, \\ Beijing, China \\ aguoqing_ruc@139.com
}

Keywords: Incremental reform, financial industry, reform evaluation

\begin{abstract}
Incremental reform as a kind of progressive reform, is one of the valuable experiences that China's reform gained in the past three decades. This paper chose financial industry as an example. We first combed the practical experience of the reform of the financial industry. Then we analyzed the effect of incremental reform in the financial sector. We came out some suggestions for further industry reform in the last part of the paper.
\end{abstract}

\section{Introduction}

In the past 30 years, China gradually formed an "incremental reform" path, which was a valuable reform experience. By studying the incremental reform of practice for a specific industry, we could get some indications and suggestion for the deepening reform in the future in China.

China's financial reform has gained brilliant achievements, at the same time it was full of twists and controversy. In general, after the reform the financial sector has become a relatively competitive industry than ever before. The financial industry has been a core industry of the national economy, and giving effectively support to the other departments of national economy, which satisfied need for financial services of the rapid economic growth.

\section{Incremental Reform Practice for Financial Industry}

In terms of institution incremental reform, it is mainly by introducing new market participants to make the market be more competitive. Before the Third Plenary Session of the 11th Central Committee of the Chinese Communist Party, the basic characteristics of China's financial sector was the limited structure and business scope, and the management system was highly centralized. The importance of the financial industry was not as big as other industries in the national economy. Thus, the role that the financial industry played could not be fully played. After the financial system reform started in 1978, the banks were set up according to the industry, and the banks stylized by industry were shown up. Banks such as Agricultural bank of China, bank of China, China construction bank successively established or resumed in 1979. Founded in 1984, the industrial and commercial bank of China mainly undertook commercial credit and savings business.

In terms of mechanical incremental reform, the reform were mainly about constructing the institution, interest and exchange rate marketization, improving the laws and regulations. For the financial organization system, the first was to developed a batch of non-bank financial institutions. The second was to form a batch of insurance companies; The third was to develop the securities industry. The last was to establish trust and investment companies, finance companies. With respect to the financial management system, the reform were mainly about decentralization, introducing competition mechanism and market mechanism, implementing the overlap of business between Banks, making the market more competitive. In terms of marketization of interest rate, exchange rate, by drawing lessons from the other countries all over the world, the government first made the money market and bond market interest rate become marketized, and then made the deposit and lending interest rate marketized. Through the reform of interest rate, the terms and the categories of the interest became more abundant, and the pricing ability of the financial institutions was strengthening. For the laws and regulations, the state council decided to set up the securities 
committee of the state council and the securities supervision and administration commission in October 1992. The law of the People's Republic of China people's bank of China, the "commercial bank law", the "instrument law", and the "insurance law” were issued in March 1995 successively.

Table 1 The marketization process of financial industry in China(1978-2013)

\begin{tabular}{|l|l|}
\hline I Releasing the inter-bank money market interest rates \\
\hline January 1986 & $\begin{array}{l}\text { The state council promulgated the bank management provisional } \\
\text { regulations, which specified the lending of money between professional } \\
\text { banks, and the money lending terms and interest rates could be negotiated } \\
\text { by both borrowing parties through consultation. }\end{array}$ \\
\hline March 1990 & $\begin{array}{l}\text { Issued the trial measures on settling interbank lending management, which } \\
\text { determined the lending rates shall implement obeying the principle of the } \\
\text { upper management. June 1, 1996, the central bank released the interbank } \\
\text { lending rates. }\end{array}$ \\
\hline II Releasing the bond market interest rates \\
\hline 1991 & $\begin{array}{l}\text { Treasury bonds began to adopt the issuing way of off-take underwriting } \\
\text { which concluding the market factors. }\end{array}$ \\
\hline June 1997 & $\begin{array}{l}\text { Central bank issued the announcement on the inter-bank bond epurchasing } \\
\text { related problems, which made the inter-bank bond repurchase rate and the } \\
\text { cash market price become more marketization. }\end{array}$ \\
\hline August 1998 & $\begin{array}{l}\text { CDB for the first time issued the financial bonds by public bidding } \\
\text { through the central bank bond issuance system, which made the issuing of } \\
\text { financial bonds for policy Banks become more marketization. }\end{array}$ \\
\hline October 1999 & $\begin{array}{l}\text { Treasury bonds issued adopted market bidding forms, thus thoroughly } \\
\text { completed the municipal bond market interest rates toward marketization. }\end{array}$ \\
\hline
\end{tabular}

III Releasing the foreign currency lending and deposit rates

\begin{tabular}{|l|l|}
\hline September 2000 & China's foreign currency interest rates began to reform management
\end{tabular} system, first releasing the foreign currency interest and the loan interest rates above $\$ 3$ million, including 3 million, the small foreign currency deposit interest rates below $\$ 3$ million was under the central bank unified management.

\begin{tabular}{|l|l|l|}
\hline July 2003 & Releasing the pound, Swiss franc and Canadian dollar small foreign
\end{tabular} currency deposit rates.

\begin{tabular}{l|l} 
November 2004 & Releasing small foreign currency deposit interest rate above one-year.
\end{tabular} Leaving dollar, Japanese yen, Hong Kong dollars, euros within the one-year implementing upper limit control management.

\section{Releasing RMB deposit and lending rates}

\begin{tabular}{|l|l} 
October 1999 & The interest rates of wholesale agreement above five year and 30 million
\end{tabular} RMB was negotiated by the bank and the insurance company themselves.

August 2003

The loan interest rates of the pilot areas was allowed to rise no more than 2 times the benchmark lending rate.

\begin{tabular}{|l|l|}
\hline January 2004 & The loan interest rate floating range of commercial banks extended to the
\end{tabular} 1.7 times benchmark lending interest rate, and the loan interest rate loating range of rural credit cooperatives extended to 2 times the benchmark lending rate. On October 29, no longer set financial institutions RMB loan interest rate cap, lowering amplitude of 0.9 times the benchmark interest rate.

August 2006 Commercial personal housing loan interest rate floating range expanded to 0.85 times the benchmark interest rate. After the outbreak of the global financial crisis in 2008, further expanding the commercial individual housing loan interest rate lower limit to the 0.7 times benchmark interest 


\begin{tabular}{|l|l|}
\hline & rate. \\
\hline June 2012 & $\begin{array}{l}\text { RMB deposit interest rate floating range of the ceiling is adjusted for 1.1 } \\
\text { times the benchmark interest rate, the lower limit of the range of floating } \\
\text { interest rate adjusted to 0.8 times the benchmark interest rate. On July 6, } \\
\text { adjusting the lower limit of the loan interest rate floating range down to } \\
\text { the 0.7 times benchmark interest rate. }\end{array}$ \\
\hline September 2013 & $\begin{array}{l}\text { The China (Shanghai) free trade area overall plan pointed out the goal of } \\
\text { financial opening, suggesting “the RMB capital account convertibility, } \\
\text { financial market interest rate marketization, the use of RMB cross-border } \\
\text { can be in operation in the free trade area if the risk were under control.” }\end{array}$ \\
\hline October 2013 & $\begin{array}{l}\text { The central bank announced the operation of loans base rate quotation and } \\
\text { mechanism. }\end{array}$ \\
\hline
\end{tabular}

\section{The Effect Evaluation for Incremental Reform of Financial Industry}

The construction of the financial markets with orderly competition. China has built a comparatively complete monetary market, which including the interbank lending market, inter-bank bond market, large certificates of deposit and commercial paper market. Money market enhanced the funds flow and the lending capacity of the banks, and improved the efficiency of the monetary policy; The interest rates of monetary can sensitively reflect the cash situation of the financial institution and the currency policy of the central bank, which gradually became an important indicator for the operation of central bank monetary policy, laying a good foundation for interest rate marketization. In respect to the capital market, the bond market and the stock market was growing rapidly and gradually formed a multi-hierarchical market system, supplying a good foundation for the structure and product of the capital market.

The establishment of a clear and specific financial regulatory system. Since China's reform and opening up, China has published a series of financial laws and regulations and established the legal framework through a series of bank and non-bank, securities and insurance regulatory legislation. China also constructed a separate operation and separate supervision of the financial system in order to meet the diversified financial institutions, financial business and competition pattern. Through the reform of the central bank regulatory system, China established the regulatory system for the securities, insurance and banking industries. At the same time, the regulating tools were diversified in the process of the reform of financial supervision mode, making the financial regulatory system being improved, which played an important role in stimulating the growth of the economy.

The coordination and cooperation of financial supervision still need to be improved. China's financial regulators and regulatory system reform has made some considerable progress in recent years. A series of laws were published, and the legal framework for financial supervision and regulation were gradually on track. The organization system of financial regulation was established, and some measures were taken to prevent and resolve financial risk. While at the same time, it should be noted that there are still some obvious flaws, such as the lack of integrity of regulatory policy framework, market access management, compliance regulation, risk supervision, external supervision, etc, still need to be modified. All of these can be serious problem for the financial industry and even for the national economy.

\section{Lessons and Indications From the Incremental Reform of Financial Industry}

From incremental reform to the stock reform. The "stock" part of the old system were kept unchanged temporarily, and the new institution and mechanism were pushed out in the "incremental" part of system. With the "incremental" part became large enough, it fed back the "stock" part. Then the reform of the "stock" part began and the whole system finished the reform procedure.

Be caution for the mergers and acquisitions of the firms in the industry. Efficient competition is based on the improvement of the competitive mechanism and environment, not a 
simple increase of market entities. To increase the competition by splitting the market entities can lead to the loss of economies of scale efficiency, and increase the cost of reform.

Implementing the reform path according to industry characteristics. Market-oriented reform is to achieve competition efficiency and improve the performance of the industry. While the different characteristics of different industries required that the reform cannot follow a single path. As the financial industry in this paper, the scientific reform path should first increase the new competition entities and then realized the price decided by the market.

\section{References}

[1] J.Y. Liang, X.H. Wang and Gang Yang: The Research on the Effect of Incremental Reform for Financial Industry in the Countryside. Issues in Agricultural Economy. Vol. 22-28(2012), p. 3

[2] Zheng Wang: The Discussion on the Incremental Reform of Bank Industry. Northern Economy and Trade. Vol. 72-73(2003), p.10 